\title{
Proximate Composition, Fatty Acid Profile and Mycotoxin Contamination in Several Varieties of Mexican Maize
}

\author{
Silvia Denise Peña Betancourt, Rey Gutiérrez Tolentino, Beatriz Schettino
}

Toxicology Laboratory Department of Agricultural and Animal Production, Autonomous Metropolitan University, Mexico City, Mexico

Email: spena@correo.xoc.uam.mx

How to cite this paper: Betancourt, S.D.P., Tolentino, R.G. and Schettino, B. (2017) Proximate Composition, Fatty Acid Profile and Mycotoxin Contamination in Several Varieties of Mexican Maize. Food and Nutrition Sciences, 8, 865-872. https://doi.org/10.4236/fns.2017.89062

Received: March 4, 2017

Accepted: September 18, 2017

Published: September 21, 2017

Copyright (c) 2017 by authors and Scientific Research Publishing Inc. This work is licensed under the Creative Commons Attribution International License (CC BY 4.0).

http://creativecommons.org/licenses/by/4.0/

\begin{abstract}
In Mexico maize (Zea mays L.) is an important cereal due to excellent taste and nutritional value. Nutritional content and fatty acid profile has been reported in white maize, however, there are several genotypes natives (red, yellow, black, blue, pinto), and many improved hybrids maize of which little is known. Fumonisins and aflatoxins are mycotoxins present in $25 \%$ of the world's cereals, mainly in tropical and subtropical regions around the world. This study presents the analysis of proximate composition (ash, protein, lipids), as well as mycotoxins (fumonisins and aflatoxins) and five different fatty acids, two of saturated fatty acids (palmitic and stearic) and three of polyunsaturated fatty acids (oleic, linoleic and linolenic), evaluated by Gas Chromatography and Flame Detector (GC-DF). Thirty varieties of maize (native and hybrid maize) were collected in states of central region. The total fumonisins were determined using the QuickTox TM extraction and quantificated by QuickScan fumonisins; the aflatoxins were analyzed by commercial ELISA kit. The highest protein level was $10.43 \mathrm{~g} / 100 \mathrm{~g}, 5.63 \mathrm{~g} / 100 \mathrm{~g}$ for fat, 1.62 $\mathrm{g} / 100 \mathrm{~g}$ for ash in hybrid maize. In native maize, the highest levels of protein and ash were $10.94 \mathrm{~g} / 100 \mathrm{~g}$ and $1.45 \mathrm{~g} / 100 \mathrm{~g}$ for pinto maize. The higher value for fat was $5.45 \mathrm{~g} / 100 \mathrm{~g}$ in yellow maize. The palmitic and stearic acids, in native maize were higher that hybrid maize, for linoleic acid and linoleinic fatty with a significant difference between native corn. Fumonisins and aflatoxins were contaminated in all genotypes of maize, in allow levels. This information obtained may be considered in maize breeding programs, industrialization processes and healthy diets.
\end{abstract}

\section{Keywords}

Zea mays L., Fatty Acid Profile, Fumonisins, Aflatoxins, Mexican Corn 


\section{Introduction}

Zea mays L., is a popular cereal in Mexico, due to taste and availability in the year. The taste is good due unsaturated fatty acids, such as linoleic and oleic acids. In Mexico, the several varieties of corn are founded in the states of central region; we can see genotypes natives of different colors as red, black, blue, yellow, pinto and white, or hybrid maize. All of them have an economic relevance and have been traditionally marketed and widely consumed directly as food or processed food [1]. The corn contains principally carbohydrate, but the lipids and ash levels are high too. It is reported fat contains in $2.17 \%$ to $4.43 \%$; $4.5 \%$ to $9.87 \%$ protein and $1.4 \%$ to $3.3 \%$ ash [2] [3]. The maize contains monounsaturated fatty acids (MUFA), primarily oleic acid or polyunsaturated fatty acids (PUFA) as linoleic acid, two important lipids with physiological functions, as protect of the hearth in acute myocardial damage, or diabetes because insulin resistance is inversely associated with deficient intake of long chain fatty acids or an increase in palmitic acid or a deficiency in linoleic acid [4]; so its regular consumption has favorable. In addition, the environmental temperature has a special influence on the profile of fatty acids in maize, which increases the proportion of saturated fatty acids at the expense of unsaturated ones [5]. In spite of this, there is no specification for the fatty acid profile in raw maize, which limits the orientation of the national breeding programs for the production of maize with a specific fatty acid composition in accordance with the current health demands of consumers [6].

The fumonisins and aflatoxins are mycotoxins produced by microscopic fungi as Fusarium verticillioides and Aspergillus flavus can be founded in tropical and subtropical regions around the world. The ingestion of these mycotoxins had been related with cancer in South Africa and Chine principally, however, monitoring for these mycotoxins in maize is not routinely performed in many countries including Mexico. Therefore, the present work aims to characterize the profile of fatty acids in commercial maize (native and hybrid) and mycotoxins contamination [7].

\section{Materials and Methods}

\subsection{Maize Samples}

Maize samples were donated by Institute of agricultural and forestry research (INIFAP), Morelos, and producers to Hidalgo and Mexico city they were collected in bags with proper identification.

\subsection{Chemical Analyses}

Moisture content of samples was determined using the direct drying method. Homogenized sample ( $10 \mathrm{~g}$ ) was dried in an oven at $60^{\circ} \mathrm{C}$ for $24 \mathrm{~h}$. The samples were powdered.

The analyses of lipid, ash and protein total were carried out following the methods described by AOAC [8]. Ash content analysis. Two grams of the dried 
sample was incinerated in a muffle at $550^{\circ} \mathrm{C}$ for 4 hours. The fat content was determined using soxhlet extraction procedure, with two grams of the sample in petroleum, during 6 hours, switched off and allowed to cool for 10 minutes. Recovered solvent was transferred into an air oven $\left(100^{\circ} \mathrm{C}\right)$ for 1 hour and then cooled in desiccators and weighed. The amount of oil was calculated and expressed as percentage of original sample.

Total Protein content of the sample was determined according to the principle of the Kjeldahl technique (AOAC Method 945.01) [8]. The sample (1 g) was digested with $20 \mathrm{~mL}$ of concentrated sulfuric acid. The resulting digest was diluted and then made alkaline with $50 \mathrm{~mL} 40 \%$ sodium hydroxide. This was followed by rapid steam distillation of ammonia from the diluted digest into $25 \mathrm{~mL}$ of $4 \%$ boric acid for manual titration with $0.1 \mathrm{~N}$ hydrochloric acid. A conversion factor of 6.25 was used to convert the measured nitrogen content to protein content. All samples were analyzed in triplicate and the results are expressed as $\mathrm{g} / 100 \mathrm{~g}$ dry basis of sample

\subsection{Chromatographic Analysis for Fatty Acids}

The preparation of the methyl esters of the fatty acids (FAME) was carried out according to the procedure ISO-IDF [9] [10]. These were analyzed in a Gas Chromatograph with Flame Ionization Detector (CG-IFD), Shimadzu 2010; with auto-injector, Split (1:100). A capillary column CP-Sil 88 Supelco $\left(\right.$ SPTM $^{2560}$, Fused Silica, Cat. No. 24056) was used with $100 \mathrm{~m} \times 0.25 \mathrm{~mm}(\mathrm{di}) \times 0.20 \mu \mathrm{m}$ film thickness, using a temperature gradient program. Nitrogen was used as gas carrier; the temperatures of the injector and detector were $250^{\circ} \mathrm{C}$ and $270^{\circ} \mathrm{C}$, respectively. The initial temperature of the oven was $140^{\circ} \mathrm{C}$, which was maintained for five minutes. The temperature was then increased by $5^{\circ} \mathrm{C}$ min to $195^{\circ} \mathrm{C}$ and maintained for $1 \mathrm{~min}$. It was increased by $6^{\circ} \mathrm{C}$ minute until reaching $220^{\circ} \mathrm{C}$ and was maintained at that temperature for $20 \mathrm{~min}$. Then it was increased by $5^{\circ} \mathrm{C}$ min until reaching $249^{\circ} \mathrm{C}$ and was maintained at that temperature for $5 \mathrm{~min}$. The run time was $50.17 \mathrm{~min}$.

A standard of 37 components was also used for the identification of the fatty acids (37 Component FAME Mix analytical standard, Supelco No. Cat. 47885-U. 33). The fatty acid contents were obtained from the average of three readings and were expressed in $\mathrm{g}$ by $100 \mathrm{~g}$ of the total fat content.

\subsection{Determination of Mycotoxins}

The samples were milled to pass through a $2 \mathrm{~mm}$ sieve. The fumonisin analysis was determined by lateral flow chromatography technique and for quantification in a Quicktox Scan System reader [11]. The technique has a limit of detection (LOD) of 200 to $20,000 \mu \mathrm{g}$, which has been validated by AOAC [12].

From $5 \mathrm{~g}$ of sample and extraction with a buffer solution or PBS, an aliquot was placed on the immunological strip which is read by the reader. Aflatoxin analysis was performed following a commercial ELISA kit [13]. 


\section{Results and Discussion}

In Table 1 and Table 2, we showed the content lipid, protein, ash on dry weight basis, of thirty-eight genotypes of maize (18 native and 20 hybrid maize). The individual fatty acids are shown in Table 3 and the levels of mycotoxin (Fumonisins and aflatoxins) contamination in Table 4.

Table 1. Proximate composition (g/100g) of different varieties of native maize.

\begin{tabular}{cccc}
\hline Genotype & Total ash & Crude Fat & Crude Protein \\
\hline 1 blue & 1.36 & 5.81 & 9.26 \\
2 white & 1.07 & 4.50 & 8.40 \\
3 white & 1.23 & 5.38 & 8.20 \\
4 reed & 1.17 & 5.01 & 8.47 \\
5 white & 1.18 & 5.17 & 8.48 \\
6 reed & 1.38 & 5.47 & 9.43 \\
7 yelow & 1.44 & 5.51 & 10.42 \\
8 white & 1.41 & 5.66 & 9.94 \\
9 blue & 1.39 & 5.11 & 10.16 \\
10 white & 1.36 & 5.75 & 9.36 \\
11 reed & 1.27 & 5.24 & 8.32 \\
12 white & 1.16 & 4.48 & 8.63 \\
13 blue & 1.28 & 5.20 & 8.84 \\
14 blue & 1.30 & 5,51 & 8.88 \\
15 yellow & 1.42 & 5.40 & 9.60 \\
16 pinto & 1.45 & 5.21 & 10.94 \\
17 white & 1.39 & 5.44 & 9.80 \\
18 white & 1.47 & 5.12 & 10.41 \\
\hline
\end{tabular}

Table 2. Proximate composition $(\mathrm{g} / 100 \mathrm{~g})$ in different hybrid maize.

\begin{tabular}{cccc}
\hline Genotype & Total ash & Crude fat & Crude protein \\
\hline Orion & 1.66 & 5.04 & 12.00 \\
NA-35 & 1.56 & 5.34 & 10.22 \\
AmCCC & 1.65 & 5.38 & 10.47 \\
$305-49$ & 1.55 & 5.45 & 9.79 \\
H943A & 1.52 & 5.30 & 10.51 \\
P2394 & 1.90 & 5.16 & 11.95 \\
Tundra & 1.82 & 5.06 & 10.68 \\
H382 A & 1.75 & 5.70 & 11.87 \\
H-515 & 1.45 & 5.02 & 9.64 \\
H-516 & 1.46 & 5.13 & 9.75 \\
30A60 & 1.48 & 4.70 & 9.85 \\
H-377 & 1.61 & 6.45 & 9.89 \\
H-374-C & 1.84 & 6.16 & 10.49 \\
Ares & 1.58 & 5.91 & 10.07 \\
P-4052 W & 1.30 & 5.10 & 8.54 \\
San Andres & 1.58 & 5.34 & 10.97 \\
NB-1 & 1.65 & 5.60 & 10.95 \\
N B-11 & 1.66 & 5.93 & 10.11 \\
Eros & 1.60 & 5.70 & 9.71 \\
Zapata & 1.62 & 4.76 & 10.36 \\
\hline
\end{tabular}


Table 3. Fatty acid profile of eighteen varieties of Mexican corn.

\begin{tabular}{cccccc}
\hline Maize Genotype & $\begin{array}{c}\text { Palmitic } \\
\text { fatty acid } \\
\text { C16:0 }\end{array}$ & $\begin{array}{c}\text { Estearic } \\
\text { fatty acid } \\
\text { C18:0 }\end{array}$ & $\begin{array}{c}\text { Oleic fatty } \\
\text { acid } \\
\text { C18:1 }\end{array}$ & $\begin{array}{c}\text { Linoleic } \\
\text { fatty acid } \\
\text { C18:2 }\end{array}$ & $\begin{array}{c}\text { Linolenic } \\
\text { fatty acid } \\
\text { C18:3 }\end{array}$ \\
\hline 1 & 11.30 & 3.21 & 42.43 & 42.22 & 0.82 \\
2 & 11.72 & 3.20 & 40.30 & 43.37 & 0.87 \\
3 & 13.32 & 2.85 & 33.43 & 49.64 & 0.74 \\
4 & 13.05 & 2.02 & 34.41 & 49.67 & 0.83 \\
5 & 11.75 & 3.20 & 41.03 & 43.18 & 0.81 \\
6 & 13.02 & 2.55 & 33.92 & 49.53 & 0.95 \\
7 & 12.41 & 3.14 & 40.00 & 43.74 & 0.77 \\
8 & 10.93 & 3.88 & 42.45 & 41.84 & 0.88 \\
9 & 12.74 & 3.79 & 36.61 & 46.00 & 0.82 \\
10 & 11.42 & 3.38 & 39.34 & 45.19 & 0.65 \\
11 & 12.35 & 3.44 & 40.83 & 42.59 & 0.77 \\
12 & 11.73 & 3.64 & 41.59 & 42.23 & 0.78 \\
13 & 12.47 & 3.38 & 40.25 & 43.00 & 0.82 \\
14 & 12.02 & 3.00 & 40.91 & 43.28 & 0.78 \\
15 & 12.15 & 3.35 & 41.50 & 42.17 & 0.80 \\
16 & 12.66 & 2.94 & 40.39 & 43.19 & 0.80 \\
17 & 13.00 & 1.33 & 34.88 & 50.00 & 0.86 \\
18 & 12.55 & 3.44 & 40.27 & 43.00 & 0.78 \\
\hline
\end{tabular}

It should be noted, that protein is the nutrient with the greatest variation among the different evaluated genotypes. The white maize has the lowest content $(7.98 \mathrm{~g} / 100 \mathrm{~g})$ with respect to yellow maize and pinto $(10.01 \mathrm{~g} / 100 \mathrm{~g}$; $10.94 \mathrm{~g} / 100 \mathrm{~g}$ ), see Table 1 . This variation can be due to the effect of heterosis achieved at the selection lines. These results are similar with Vazquez et al. [14].

In the case of lipids, we could observe that the lowest total fat content, were in white and pinto genotypes (5.18 to $5.21 \mathrm{~g} / 100 \mathrm{~g}$ ), with respect to yellow maize $5.45 \mathrm{~g} / 100 \mathrm{~g}$; in hybrid maize the range content was similar to white maize native (Table 2). These results are superior to those reported by Vazquez et al. [15], with a content of $4.9 \%$ for the native maize and $3.5 \%$ for the hybrids.

The ash content is a reflection of the mineral content, was higher in yellow and pinto maize native $(1.43 \mathrm{~g} / 100 \mathrm{~g}, 1.43 \mathrm{~g} / 100 \mathrm{~g})$ showing that they might be good sources, since the lowest content in white maize $(1.28 \mathrm{~g} / 100 \mathrm{~g})$. This variation can be explained by the soil and fertilization used in agricultural field.

In Table 3, we can see that genotypes native maize $(12,13,14,15,16,18)$, the palmitic fatty acid content was lower $(12.26 \mathrm{~g} / 100 \mathrm{~g})$ than the white hybrid maize $(13.16 \mathrm{~g} / 100 \mathrm{~g})$, which means an increase of fatty acid saturated in $1 \%$ in they, however, the stearic fatty content was higher $(3.30 \mathrm{~g} / 100 \mathrm{~g})$, than observed in the hybrid maize $(2.09 \mathrm{~g} / 100 \mathrm{~g})$. Oleic acid, native maize showed a higher average content $(40.83 \mathrm{~g} / 100 \mathrm{~g})$, since the hybrid maize was minor $(34.15 \mathrm{~g} / 100 \mathrm{~g})$, it is 
Table 4. Fumonisins and aflatoxins contamination in maize, from Mexico.

\begin{tabular}{|c|c|c|}
\hline Maize genotype & Aflatoxins $(\mu \mathrm{g} \mathrm{kg})$ & Total Fumonisins ( $\mu \mathrm{g} \mathrm{kg}$ ) \\
\hline $30 \mathrm{~V} 46^{* 1}$ & 15.0 & 370 \\
\hline $\operatorname{AmCCC}^{\star 1}$ & ND & 400 \\
\hline ARES $^{\star 1}$ & ND & 230 \\
\hline DK $2060^{* 1}$ & 13.0 & ND \\
\hline $\mathrm{H}-374-\mathrm{c}^{\star 1}$ & ND & 230 \\
\hline $\mathrm{H}-377^{\star 1}$ & ND & 230 \\
\hline H- $515^{\star 1}$ & 14.5 & 230 \\
\hline H-516 $6^{* 1}$ & 15.5 & 790 \\
\hline NB- $1^{\star 1}$ & 12.0 & 230 \\
\hline NB- $11^{\star 1}$ & 17.7 & 540 \\
\hline $\mathrm{P}-2844^{* 1}$ & 15.2 & 170 \\
\hline $\mathrm{P} 4032^{\star 1}$ & 15.0 & 1000 \\
\hline $\mathrm{P}-4082^{* 1}$ & ND & 230 \\
\hline San Andrés ${ }^{* 1}$ & ND & 230 \\
\hline Tundra $^{\star 1}$ & ND & 350 \\
\hline V5335 & 15.0 & 1200 \\
\hline Average standard deviation & $14.8( \pm 1.7)$ & $13.4( \pm 1.4)$ \\
\hline $30 \mathrm{G} 60^{* 2}$ & 14.5 & 230 \\
\hline $30 \mathrm{~T} 26^{\star 2}$ & 12.0 & 230 \\
\hline Bengala $^{\star 2}$ & 13.5 & 790 \\
\hline Wild ${ }^{\star 2}$ & 18.0 & 130 \\
\hline Wild ${ }^{\star 2}$ & 10.0 & ND \\
\hline Wild ${ }^{\star 2}$ & 13.0 & ND \\
\hline Leopardo ${ }^{\star 2}$ & 17.0 & 660 \\
\hline Oso $^{\star 2}$ & 13.0 & 250 \\
\hline Pantera $^{\star 2}$ & 13.0 & 230 \\
\hline Puma $^{\star 2}$ & 10.0 & 220 \\
\hline
\end{tabular}

${ }^{{ }_{1}}$ Zacatepec, Morelos region. ${ }^{{ }^{*}}$ Tlaxcoapan, Hidalgo region.

one of fat which reduce low density lipoprotein (LDL) and cholesterol in the body, helping to protect against coronary heart disease, unfortunately it was decreased in $6.68 \mathrm{~g} / 100 \mathrm{~g}$ in hybrid maize.

The linoleic fatty acid was higher for the hybrids $(49.82 \mathrm{~g} / 100 \mathrm{~g})$ than the observed in the native maize $(42.81 \mathrm{~g} / 100 \mathrm{~g})$. The genotypes $3,6,17$ contain the highest levels of the palmitic fatty acid, the genotypes $1,5,8,14,15$ of the fatty ac oleic; 4, 6, 17 of linoleic fatty ac and 6 and 8 ac linolenic. The genotypes that presented the lowest content in oleic acid were 3, 6, 17 for linoleic acid 8, 12 and 15 and for linolenic acid the genotype 10. This information can be used to replace carbohydrates in diabetic patients diet.

All samples analyzed were contaminated with at least one mycotoxin and the 
levels very close to the maximum content allowed for both mycotoxins, mainly in genotypes developing in warm places as Morelos state Table 4.

\section{Conclusions}

It is concluded that the protein is the nutrient with the greatest variation among the different evaluated genotypes, with variations in the saturated and unsaturated fatty acid content, which must be specified and regulated in order to provide a food with the best levels of fatty acids required by the consumer. The hybrid maize has lost monounsaturated fatty acids (MUFA), primarily oleic acid in 7\%, however, it gained in polyunsaturated fatty acids (PUFA) as linoleic acid. The coexistence of two mycotoxins in the maize hybrids was showed, however, at levels within the international regulation for aflatoxins and fumonisins, but it is not safe for all the people.

The knowledge of the lipid profile of corn in Mexico may help the diet of people suffering from chronic degenerative diseases.

\section{References}

[1] Sánchez, G.J.J. (2011) Maize Diversity and the Teocintle. Report Prepared for the Project: Compilation, Generation, Updating and Analysis of Information about of the Genetic Diversity of Maize and Its Wild Relatives in Mexico. National Commission for the Knowledge and Use of Biodiversity. Manuscript. 2. Paper reviewed by Hugo Perales (ECOSUR) and Fernando Castillo (COLPOS).

[2] Venegas, G.M.R. (2016) Maize Production and Marketing in Mexico. 21 Meeting on Regional Development in Mexico.

[3] Enyisi, I.S., Umoh, V.J. and Whong, C.M. (2014) Chemical and Nutritional Value. Journal of Food Science and Technology, 5, 100-104.

[4] Flock, M.R., Harris, W.S. and Kris, E.P. (2013) Long Chain Omega 3 Fatty Acid. Time to Establish a Dietary Reference Intake. Nutrition Reviewers.

[5] Hu, F.B., Cho, E., Rexrode, K.M., Albert, C.M. and Manson, J.E. (2003) Fish and Long-Chain $\omega-3$ Fatty Acid Intake and Risk of Coronary Heart Disease and Total Mortality in Diabetic Women. Circulation, 107, 1852-1857. https://doi.org/10.1161/01.CIR.0000062644.42133.5F

[6] Wong, K.V. (2016) Optimization of Healthy Fats in One Daily Diet. EC Nutrition, 5, 1232-1237.

[7] Peña, B.S.D., Valladares, C.B. and Posadas, M.E. (2015) Estimation of Mycotoxins Multiple Contamination in Mexican Hybrid Seed Maize by HPLC-MS/Ms. Agricultural Sciences, 6, 1089-1097. https://doi.org/10.4236/as.2015.69104

[8] (1990) Association of Official Analytical Chemists. 15th Edition, AOAC, Official Methods of Analysis, Arlington.

[9] Bligh, E.G. and Dyer, W.J. (1959) A Rapid Method of Total Lipid Extraction and Purification. Canadian Journal of Biochemistry and Physiology, 37, 911-917. https://doi.org/10.1139/059-099

[10] ISO-IDF. (2002) Milk Fat-Preparation of Fatty Acid Methyl Esters. International Standard ISO 15884-IDF 182: 2002. International Organisation for Standardisation (ISO), Geneva, Switzerland.

[11] Polanski, S. (2015) Quicktox TM Kit for Fumonisins. Journal of AOAC 
International, 98, 1571-1584.

[12] Peña, B.S. (2006) Detection of Fumonisins in Maize (Zea mays L.) by Three Analytical Techniques (HPLC, TLC and ELISA). In: Njapau, H., Sócrates, T., van Egmond H. and Park, D., Eds., Mycotoxins and Phycotoxins Advances in Determination, Toxicology and Exposure Management, Wageningen Academic Publishers, The Netherlands.

[13] Vázquez, C.M.G., Mejía, H., Salinas, Y. and Santiago, D. (2013) Effect of Population Density on Grain Quality, Nixtamal and Tortilla of Maize Hybrids of High Protein Quality. Rev. Fitotec. Mex., 36, 225-232.

[14] Vázquez-Carrillo, G., García-Lara, S., Salinas-Moreno, Y., Bergvinson, D.J. and Palacios-Rojas, N. (2011) Grain and Tortilla Quality in Landraces and Improved Maize Grown in the Highlands of Mexico. Plant Foods for Human Nutrition, 66, 203-208. https://doi.org/10.1007/s11130-011-0231-7

[15] Vázquez, C.M.G., Pérez, J.P., Hernández, J.M., Marrufo, M.L. and Martínez, E. (2010) Quality of Grains and Tortillas of Native Maize from Altiplano and Mezquital Valley. Rev. Fitotec. Mex., 33, 49-56.

\section{Scientific Research Publishing}

\section{Submit or recommend next manuscript to SCIRP and we will provide best} service for you:

Accepting pre-submission inquiries through Email, Facebook, LinkedIn, Twitter, etc. A wide selection of journals (inclusive of 9 subjects, more than 200 journals)

Providing 24-hour high-quality service

User-friendly online submission system

Fair and swift peer-review system

Efficient typesetting and proofreading procedure

Display of the result of downloads and visits, as well as the number of cited articles

Maximum dissemination of your research work

Submit your manuscript at: http://papersubmission.scirp.org/

Or contact fns@scirp.org 